TEME, г. XLI, бр. 1, јануар-март 2017, стр. 259-275

Прегледни рад

DOI: 10.22190/TEME1701259R

Примљено: 01. 11. 2015.

UDK 37.016:796.011.1

Ревидирана верзија: 24. 12. 2016.

Одобрено за штампу: 17. 01. 2017.

\title{
УЛОГА И ЗНАЧАЈ ШКОЛСКОГ СПОРТА У ПРЕВЕНЦИЈИ НАСИЉА
}

\section{Сандра Раденовић", Слађана Мијатовић}

Универзитет у Београду, Факултет спорта и физичког васпитања, Београд, Србија

*sandra.radenovic@fsfv.bg.ac.rs

\begin{abstract}
Апстракт
Циљ овог рада јесте разматрање значаја школског спорта као мере превенције насиља међу ученицима у школама у Србији. У уводу ауторке разматрају основне дефиниције насиља, бројне облике насиља у спорту, насиље у школама, насиље младих и малолетничку делинквенцију као облике насиља који се изучавају у социологији, психологији, педагогији и другим хуманистичким дисциплинама. Ауторке наводе резултате истраживања распрострањености и облика насиља у школама у Србији које је спроведено 2011. године. Упркос доношењу и спровођењу стратешких докумената (Посебни протокол за заштиту деце и ученика од насиља, злостављања и занемаривања у образовно-васпитним установама, 2007; Правилник о протоколу поступања у установи у одговору на насиље, злостављање и занемаривање, 2010) који предвиђају мере превенције насиља у школама, степен насиља у нашој средини остао је непромењен у односу на претходна истраживања. Ови стратешки документи не препознају значај могућности школског спорта као мере превенције насиља. Ауторке предлажу могућност осмишљавања програма који би кроз систем школског спорта били мера превенције насиља у школама и начин унапређења спортске и физичке културе у најширем смислу.
\end{abstract}

Кључне речи: насиље, насиље у школи, школски спорт, превенција насиља

\section{THE ROLE AND IMPORTANCE OF SCHOOL SPORT IN THE PREVENTION OF VIOLENCE}

\footnotetext{
Abstract

The aim of this paper is the proposal considering the importance of school sport as a measure of prevention of violence among students in schools. In the introduction the authoresses discuss the basic definitions of violence, numerous forms of violence in sport, violence in schools, youth violence and juvenile delinquency as the forms of violence which are studied in sociology, psychology, pedagogy and other humanities. The authoresses present the results of the research of prevalence and forms of violence
} 
in schools in Serbia according to the report from 2011. Despite the implementation of certain strategic documents (Special Protocol for the Protection of Children and Students from Violence, Abuse and Neglect in Educational Institutions, 2007, Rule book on the Protocol for Treatment in the Institution in the Response to Violence, Abuse and Neglect, 2010) which specify measures for the prevention of violence in schools, the level of violence has remained unchanged compared to the previous researches. These strategic documents do not recognize the importance of the possibility of school sport as the measure of prevention of violence. The authoresses suggest the possibility of designing programmes within the system of school sport as the measure of prevention of violence in schools and the way of improving sport culture and physical culture in the broadest sense.

Key words: violence, violence in school, school sport, prevention of violence.

\section{УВОД}

Насиље се најчешће дефинише као облик испољавања агресивног понашања или агресије, при чему се улаже свестан напор да се изазове повреда или бол. Могу се издвојити два основна типа агресивног понашања, и то: реактивни и инструментални тип. Док је реактивни тип агресије резултат физичке или психичке казне која је више сврха него што је средство, инструментални тип агресије укључује намеру да се зада бол и/или нанесе повреда, а што је средство да се постигне одређена сврха, рецимо, новац, победа итд. (Трипковић, 2007; Раденовић, 2012). Социолози наводе веома широку дефиницију насиља као свега оног што принудно спутава и ограничава реализацију и развој позитивних људских потенцијала, па тако дефинисано насиље може обухватити све оне поступке и активности који се могу означити као употреба или претња субјекта насиља, односно извршиоца насиља (насилника) употребом силе у односу на објект насиља, то јест жртву, без обзира на то о којој врсти силе се ради, и то у циљу да се жртви, посредно или непосредно, нанесе физички бол или психичка бол (страх и патња), а како би се понашање жртве ставило под контролу извршиоца насиља. Отуда се може говорити о физичком и психичком, рационалном и ирационалном, директном и индиректном, индивидуалном и друштвеном, тренутном и дуготрајном, групном (масовном) и појединачном, манифестном и латентном, грубом и фином (суптилном) насиљу итд. (Трипковић, 2007; Раденовић, 2012). Рецимо, различити облици физичког или психичког насиља карактеришу насиље над особама са инвалидитетом као специфичан феномен који заокупљује пажњу истраживача различитих профила (Бењак, Штефанчић, Иванић \& Драушник, 2016). Како се истиче у релевантној криминолошкој литератури (Спасић, 2013), постоји и класификација насиља која разликује психичко од менталног насиља, рационално од ирационалног насиља, активно од пасивног и деструктивно од конструктивног насиља. Може се закључити да се различите класификације насиља користе и за објашњење природе и карактеристика насиља, 
односа између извршиоца, жртве и окружења у којем се насиље дешава (Спасић, 2013).

\begin{abstract}
„На пример, насиље на јавном месту може укључивати и застрашивање, претње, физичко или сексуално злостављање, било да су у питању познаници или странци. Са друге стране, злостављање деце у кући може да укључи психичко, физичко и сексуално злостављање и занемаривање” (Спасић, 2013, стр. 226).
\end{abstract}

Најзад, сматра се да је најчешће испитиван облик насиља директно или интерперсонално насиље (Бабовић, 2015). Овом облику насиља највише се пажње посвећује у психологији, праву и области практичних политика. Директно насиље јесте онај облик насиља у коме су субјекат и објекат директно повезани, без обзира на то да ли је реч о појединцима, групама или неким другим колективним актерима. Како подсећа ауторка (Бабовић, 2015), код директног насиља постоје: актер који врши насиље, објекат насиља, који је жртва насиља, и акција, односно чин насиља. Директно насиље може бити физичко, сексуално, економско или психолошко, а може се одвијати како у сфери приватних и породичних односа тако и у широј друштвеној заједници и оно укључује веома различите форме, као што су: „вршњачко насиље, насиље према женама, злостављање путем интернета, сексуално насиље, тортуре, убиства, ратове и социјалне немире" (Бабовић, 2015, стр. 335).

Насиље у спорту је веома битна тема која се изучава у оквиру социологије спорта као посебне социолошке дисциплине. Иако се у већини истраживања у социологији спорта насиље у спорту препознаје превасходно на трибинама, у социолошкој литератури може се наћи следећа „груба” подела насиља: 1. насиље гледалаца (публике); 2. насиље спортиста (насилни поступци и потези током саме игре, вербални и физички обрачуни између играча); 3. насиље родитеља над децом спортистима; 4. насиље тренера; 5. насиље над спортским судијама (Антонић, 2015; Коковић, 1990).

Социолози спорта покушавају да објасне све чешћу појаву насиља на спортским стадионима постављајући нека од следећих питања:

„Зашто и због којих потреба навијачи долазе на стадион?; Да ли посматрају утакмицу и при том уживају у навијању без сукобљавања или долазе превасходно с намером да изазову сукобе и туче?" (Коковић, 2010, стр. 125).

Одговори на ова и слична питања налазе се у дубљим друштвеним узроцима: често је реч о феномену идентификације који претпоставља исказивање групне припадности и који има елементе вредносног опредељења. Тако припадност навијачким групама даје осећај моћи, утицаја, значаја и јесте потрага за властитим идентитетом, али и 
врста 'вентила' као бег од свакодневице (Раденовић, 2014; Коковић, 2010). Када је реч о насиљу спортиста, истраживачи махом говоре о насиљу над самим собом, те о насиљу и сукобима са спортистима из другог тима, али и о ретким облицима насиља према спортистима из властитог тима, када је реч о групним спортовима. Ради постизања победе по сваку цену, спортисти прибегавају употреби насиља некада са јасним циљем да повреде противника, а некада само ради застрашивања.

„Данас се агресивна игра јавно афирмише и углавном је заснована на борилачком нагону да се противник заустави и спречи по сваку цену, како не би дошао у ситуацију да оствари победу" (Антонић, 2015, стр. 14).

Победа по сваку цену и остваривање све већег профита у систему спорта јесу узроци насиља које спортисти спроводе над самим собом. Реч је о све чешћој употреби допинга као латентном насиљу, за разлику од поменутих облика манифестног насиља између спортиста (Антонић, 2015). Насиље родитеља над децом спортистима јесте још један значајан и веома заступљен облик насиља који још није довољно истражен. Насилно понашање родитеља према деци спортистима огледа се у психолошком притиску који родитељи врше над децом, нереалним очекивањима, сталним критикама, непримереним понашањем на тренингу или током утакмица, екстремним жељама да њихово дете једног дана буде попут професионалних и познатих спортиста. Све су то бројни негативни утицаји на понашање деце, њихову психу, социјалну интеракцију, те даље учешће у спорту (Антонић, 2015). Насиље тренера над спортистима најчешће се односи на психолошко насиље, ређе је реч о физичком насиљу. Наиме, испољавање беса, љутње, нервозе од стране тренера дешава се током утакмица и тренинга када спортиста погреши, начини непотребан фаул, не одигра добро или пак на тренингу има неозбиљан приступ и не залаже се довољно итд. Начин испољавања беса и љутње од стране тренера може бити подстицај за спортисту да игра боље, али каткад може деловати и демотивишуће. Поменимо укратко и насиље над спортским судијама од стране спортиста или публике као још један облик насиља у спорту. У већини случајева, повод је некоректно суђење.

„Тако на пример, када у фудбалу судија досуди пенал за који фудбалер сматра да га није начинио, одмах почиње негодовање и одмахивање рукама, али неретко се цела ситуација може завршити и уношењем у лице судији, гурањем, вербалним претњама“ (Антонић, 2015, стр. 21-22).

Бројни облици насиља у спорту изучавају се и у оквиру психологије, антропологије, те етике спорта. Како наводе истраживачи овог 
феномена из перспективе психологије (Оташевић \& Секереш, 2015), резултати истраживања које су спровели указују на неоправданост приписивања агресивности, импулсивности и подржавања насиља високо идентификованим спортским навијачима, односно у најширем смислу - спортским „фановима”, с обзиром на то да сама идентификација са тимом није повезана са антисоцијалним и насилним обележјима. Као чиниоци који доприносе навијачком идентитету издвајају се припадност мушком полу и маскулина оријентација ка полној улози која је изражена мачистичким ставовима и манифестном неустрашивошћу (Оташевић, et al., 2015). Дакле, иако је веома често преклапање фудбалских навијача, хулигана и посебних видова омладинских супкултура, свакако је у бројним анализама овог феномена присутно и схватање према коме навијачи нису само припадници организованих навијачких група који су одговорни за изгреде на трибинама већ је реч о особама које фаворизују одређени спортски клуб, бодре га и радују се његовим успесима, тзв. sports fans, односно спортски „фанови” (Cashmore \& Cleland, 2012; Оташевић et al. 2015).

На повезаност спортских такмичења са испољавањем агресије још у доба древних цивилизација кроз историју физичке културе и спорта упућују бројни докази (Вејновић \& Павловић, 2012). Иако ови аутори с правом сматрају да је развој цивилизације пратио пад бруталности, по којима су били карактеристични спортски догађаји, чињеница је да је насиље још увек ружно наличје спорта, ${ }^{1}$ а што се нарочито односи на оне спортске приредбе, најчешће, фудбалске утакмице које постају попришта „ритуализоване агресије” од стране бројних навијачких група (Вејновић et al. 2012, стр. 163). Када је реч о Србији и региону, односно о Хрватској и Босни и Херцеговини, насиље и са насиљем повезани догађаји око фудбалских стадиона, укључујући чак и смртне случајеве, постали су незаобилазне друштвене чињенице које се обично могу тумачити у контексту етничких конфликата, политичке нестабилности, слабих државних институција, те непрестане социо-економске кризе и са њом повезане хроничне бесперспективности за нове генерације (Вејновић, et al. 2012). Како анализира Ђорђевић (Ђорђевић, 2015; Ђорђевић, 2016), у контексту доминације етнонационализма у Србији и региону, навијачке групе не

\footnotetext{
${ }^{1}$ Чињеница је да су веома бројна она истраживања у оквиру различитих хуманистичких дисциплина која се баве облицима насиља у спорту, односно поменутим ружним наличјем спорта. Но, поменимо истраживање које указује на друго, позитивно лице спорта, односно на значајну улогу спорта у дипломатији (Bašelj, 2015). Аутор сматра да је спорт веома важан део међународних односа, спорт утиче на дипломатију и спољну политику, те може побољшати „имиџ” државе у свету, тако да спорт може бити веома корисно оруђе у дипломатији једне земље ако је на добар начин искоришћен (Bašelj, 2015).
} 
наилазе на осуду да су хулиганске, јер им легитимет даје наводни патриотизам у функцији апсолутне националне хомогенизације. Тако су навијачке групе постале нека врста озбиљног политичког фактора чије се мишљење и ставови ослушкују и цене, па се процес „својеврсне инструментализације навијача и навијачких група” у политичке сврхе ${ }^{2}$ наставио и након петооктобарских промена у Србији, када је био највидљивији (Ђорђевић, 2016, стр. 437).

Из перспективе етике спорта, сматра се да све чешћа појава драстичног кршења етичких кодекса спортиста и моралних кодекса навијача, спортских клубова, спортских организација и спонзора спорта све више постаје проблем који може не само да угрози социјалну и еколошку средину већ у знатној мери утиче на систем вредности спортиста и навијача (Јовановић, 2013). Наиме, када спортисти и навијачи својим ставовима и понашањем на спортским приредбама не поштују универзалне људске вредности и посебне позитивне вредности које се спортом одржавају и развијају, тиме заправо ометају или онемогућавају остваривање позитивног смера свог смисла живота (Јовановић, 2013).

Насиље у школама, насиље младих и малолетничка делинквенција јесу облици насиља који се изучавају у социологији, психологији, педагогији и другим хуманистичким дисциплинама. Најчешће су насиље младих, те малолетничка делинквенција у вези са испољавањем хулиганизма и вандализма у оквиру организованих навијачких група, па су отуда веома значајне теме којима се бави социологија спорта. Наиме, насиље у спорту се објашњава различитим теоријским моделима: моделом катарзе, моделом културе и поткултуре, моделом социјалног учења, моделом психологије гомиле, те девијантним моделом у који се најчешће убрајају вандализам и хулиганизам (Коковић, 2010). Хулиганизам обухвата безобзирну, бескорисну, бесциљну радњу праћену општим изражавањем презира према појединцима или друштву у целини, понашање које грубо нарушава јавни поредак и изражава очигледан презир према друштву. Хулигани се жестоко супротстављају органима реда, односно полицији, јер у њој виде највећег и најнепосреднијег супарника који за њих јесте представник званичног друштва и доминантног система вредности, а које они одбацују и против којих се боре. Битно је подсетити на често преклапање фудбалских навијача, хулигана и посебних видова омладинских супкултура. Неретко навијачке супкултуре

\footnotetext{
${ }^{2}$ Инструментализација навијача и навијачких група у политичке сврхе јесте веома значајна тема када је у питању насиље у спорту у Србији и земљама окружења, нарочито у Хрватској и Босни и Херцеговини, но, свакако да превазилази оквире овог рада. О инструментализацији навијача у политичке сврхе детаљно говори Ђорђевић (Ђорђевић 2015; Ђорђевић 2016).
} 
регрутују у своје редове припаднике културе сиромаштва, као и маргиналце које стратегија преживљавања, животни неуспеси, неуспеси у школи и сталне фрустрације чине негативистички расположеним и малициозним, спремним за несврховито понашање (на пример, учествовање у ситним крађама не због материјалне користи, већ због кршења реда и ради чињења нечег забрањеног). „Сматра се да се оваквим понашањем ови појединци покушавају да супротставе својим животним проблемима и неуспесима" (Коковић, 2010, стр. 160). Вандализам се дефинише као савремена појава која се манифестује кроз најразноврсније обрасце попут уништавања имовине (телефонских говорница, аутобуса, железница, биоскопских дворана, станова, фасада, аутомобила) и најчешће се повезује са насиљем. Без обзира на то што није дефинисан у појединачним националним кривичним законима, вандализам као негативна друштвена појава постоји у свим друштвима (Коковић, 2010; Раденовић, 2014). С обзиром на наведено често преклапање фудбалских навијача, хулигана и посебних видова омладинских супкултура, поменимо и везу спортског клађења са другим ризичним понашањима која могу произвести и хулиганизам. Наиме, новија истраживања преваленције коцкања младих (Рицијаш, Хундрић \& Кранжелић, 2015), која све више заузимају средиште разматрања стручњака у хуманистичким дисциплинама, показују значајну заступљеност овог понашања, док теоријски модели, али и бројна емпиријска истраживања спроведена у свету, говоре у прилог повезаности коцкања са другим облицима ризичног и делинквентног понашања. Резултати истраживања спроведеног у суседној Хрватској показују да се чак $36,6 \%$ средњошколаца редовно клади на спортске резултате, да је спортско клађење најучесталији облик коцкања код младих и да средњошколци који се редовно кладе показују и више других облика ризичног, односно делинквентног понашања, попут проблематичног понашања у школи, као и конзумирања средстава која изазивају зависност (Рицијаш, et al. 2015). Како са порастом проблема повезаних са коцкањем расте и вероватноћа чињења бројних казнених дела, требало би имати на уму да би се правовременим и стручним препознавањем проблема на овом нивоу и пружањем адекватног третмана у склопу казненоправних санкција посредно допринело и смањењу стопе рецидивизма малолетних починитеља казнених дела (Рицијаш, et al. 2015).

Можемо закључити да су неопходна даља истраживања повезаности различитих облика ризичног и делинквентног понашања младих са хулиганизмом, вандализмом, припадношћу навијачким групама и, у најширем смислу, са формирањем идентитета навијача, односно „спортског фана”. 


\section{НАСИЉЕ У ШКОЛИ - РАСПРОСТРАЬЕНОСТ И ОБЛИЦИ У ИЗВЕШТАЛУ , ЗАШТИТА ДЕЦЕ ОД НАСИЉА У ШКОЛАМА”}

У овом делу рада навешћемо резултате истраживања распрострањености и облика насиља у школама Србије. Реч је о истраживању које је спроведено методом анкетирања анонимном анкетом у 72 школе, и то у 37 основних и 35 средњих школа са територије централне Србије и АП Војводине (Заштитник грађана, 2011). Према резултатима овог истраживања, насиље у школама се јавља у следећа два облика: 1 . насиље међу ученицима и 2. насиље наставника према ученицима. ${ }^{3}$ Само $6 \%$ ученика у основним и $23 \%$ ученика у средњим школама навело је да није имало искуства са неким обликом насиља међу ученицима. Ово истраживање потврђује резултате претходних истраживања насиља међу ученицима који упућују на податак да се у основним школама најчешће врши насиље старијих ученика над млађим ученицима. „Тако деца у нижим разредима наводе да старији ученици над њима врше насиље, тачније ударају их и узимају ствари" (Заштитник грађана, 2011, стр. 20). Када је реч о насиљу наставника према ученицима, поменуто истраживање потврђује налазе претходних истраживања овог феномена који указују на податак да се овај облик насиља креће у распону од $20 \%$ до $30 \%$. Тако је $23 \%$ анкетираних ученика у овом истраживању навело да је било сведок неког облика насиља наставника према ученицима. Према резултатима истраживања, овај облик насиља чешће се јавља у средњим него у основним школама, те је $26 \%$ анкетираних средњошколаца навело да је имало такво искуство, док је $20 \%$ анкетираних основаца навело искуства насиља наставника према ученицима. Најзад, 74\% анкетираних средњошколаца и $80 \%$ анкетираних основаца сматра да не зна да ли је осетило неки облик насиља од стране наставника или наводи да није било злостављано од стране наставника и учитеља (Заштитник грађана, 2011).

Према досадашњим сазнањима, мере превенције насиља у школама које су предложене и предузимане од стране Министарства просвете и науке Републике Србије односе се на период после доношења Посебног протокола за заштиту деце и ученика од насиьа, злостављања и занемаривања у образовно-васпитним установама (2007. година) и после ступања на снагу Правилника о протоколу поступаға у установи у одговору на насиље, злостављане и занемаривање (2010. година). У оквиру поменутог истраживања, испитано је да ли су ученици били упознати да је школа организовала разговоре,

\footnotetext{
${ }^{3}$ У овом истраживању нису издвојени следећи облици насиља: насиље ученика према наставницима и насиље родитеља према наставницима, те на тај начин немамо потпуну слику свих облика насиља у школама које је присутно у Србији данас.
} 
трибине, дебате или обезбеђивала промотивне материјале на тему проблема насиља у школама, да ли је омогућила обуке о ненасилној комуникацији, стратегијама решавања проблема и вештинама алтернативног разрешавања конфликата и, најзад, у којој мери су ученици били укључени у те школске активности. Према резултатима истраживања, $60 \%$ анкетираних ученика сматра да у њиховој школи није предузета или не зна да ли је примењена било која од поменутих мера смањења, сузбијања и искорењивања насиља на које су школе обавезане поменутим протоколом и правилником (Заштитник грађана, 2011). Према резултатима истраживања, основне школе су у мањој мери предузимале активности у вези са превенцијом насиља иако је насиље распрострањеније у основним него у средњим школама (Заштитник грађана, 2011). Према проценама анкетираних ученика, средње школе су у нешто већој мери (53\%) у односу на основне школе $(46 \%)$ посвећене организовању и припремању разговора, трибина, дебата и промотивних материјала на тему насиља у школама (Заштитник грађана, 2011). Поменимо и то да су школе у значајно мањој мери предузимале сложеније, али ефикасније и ефективније мере превенције насиља и развијања толеранције, као што су учење социјалним вештинама и стратегијама решења проблема, стицање вештина за ненасилну комуникацију и алтернативно решење конфликата. Иако је познато да превентивне мере показују већу делотворност ако се предузимају на ранијем узрасту, активности за превенцију насиља у школама према резултатима овог истраживања значајно се више предузимају у средњим (32\%) него у основним школама (23\%) (Заштитник грађана, 2011). Најзад, поменућемо и то да резултати истраживања упућују на закључак да су се у најмањој мери примењивали прописи о заштити деце од насиља у школама у делу који се односи на обавезу школа да се формира Тим за заштиту од насиља, злостављања и занемаривања. Око $70 \%$ анкетираних ученика основних и средњих школа наводи да школа нема или не зна да ли има Тим за заштиту од насиља, злостављања и занемаривања. Добијени подаци о томе да ли ученици знају ко су чланови Тима и како могу да им се обрате у случају насиља указују на то да ни она деца (око 30\%) која знају да у школи Тим постоји нису добила потпуну и одговарајућу информацију о Тиму коју је школа дужна да им пружи, јер половина од укупног броја деце обухваћене истраживањем не зна ко су чланови Тима, а свега $2 \%$ је знало одговор на то питање (Заштитник грађана, 2011). Ово истраживање указује и на податак да скоро 90\% школа није на местима за оглашавање и информисање ученика истакло било какав податак у вези са Тимом, а чак $30 \%$ школа уопште нема огласну таблу намењену обавештавању ученика. Дакле, школе нису испуниле своју обавезу да информацију о постојању Тима за заштиту од насиља, злостављања и занемарива- 
ња и његовим члановима учине доступном свим ученицима и да имена чланова Тима буду истакнута на видном месту (Заштитник грађана, 2011). Дакле, и поред тога што су донети стратешки документи са циљем сузбијања и превенције насиља над и међу децом, степен насиља у школама остао је непромењен у односу на период пре доношења и спровођења стратешких докумената (Заштитник грађана, 2011).

Непромењен степен насиља у школама можемо да објаснимо не само све присутнијим процесом нормализације насиља ${ }^{4}$ у целом друштву већ и, како је показало истраживање, недовољним ангажовањем школа у примени поменутих стратешких докумената. У оквиру поменутих стратешких докумената не предлаже се могућност и значај школског спорта у превенцији насиља ученика. Може ли школски спорт бити ефикасно и ефективно средство у превенцији насиља међу ученицима? Ово питање размотрићемо у наредном делу рада.

\section{ШКОЛСКИ СПОРТ КАО МЕРА ПРЕВЕНЦИЈЕ НАСИЉА МЕЂУ УЧЕНИЦИМА}

Наведимо одреднице које се односе на значај школског спорта које су препознате у Стратегиј развоја спорта у Републици Србији за период 2014-2018. године.

„Школски спорт представља незаобилазну карику у промоцији активног начина живота, развоју спорта и врхунског спортског резултата. У оквиру школског спорта, школе имају централну улогу. Нужно је обезбедити да се настава физичког васпитања у потпуности реализује по усвојеним плановима и програмима и да се спортске секције реализују како је прописано. Циљ треба да буде да се деца анимирају да се баве физичким вежбањем, кроз забаву и игру, и да се задовоље основни приоритети школског спорта: свеобухватност, препознавање талената и здравствени аспект. Главни циљ школског спорта мора бити физички, интелектуални, морални, социјални и културни развој свих ученика. Исто важи и за универзитетски спорт. Када су у питању школска спортска такмичења, приоритет су такмичења унутар школа и на нивоу јединица локалне самоуправе. Потребно је, такође, организовати спортске активности деце за време распуста, посебно путем спортских кампова. Посебно је значајно предузимање активности које треба да доведу до тога да деца не плаћају чланарину у спортским организацијама, или да она буде примерена могућностима родитеља. Како би се повећало учешће деце у спорту, национални спортски савези треба да обезбеде да спортски клу-

\footnotetext{
${ }^{4}$ Реч је о процесу који донекле промовише насиље као доминанатан, прихваћен,
} уобичајен, нормалан, те пожељан облик понашања (Раденовић, 2012). 
бови уз сениорске екипе обавезно имају и дечје екипе. Циљ Републике Србије је да деца и млади усвоје потребна знања о здравим облицима физичке активности и о здравим стиловима живота и изграде правилне кретне навике" (Стратегија развоја сnорта у Републици Србији за период 2014-2018, 2014, стр. 17).

У поменутом документу истиче се и значај физичке активности и физичког васпитања у најширем смислу:

„Спорт у свим облицима треба да буде појединачно доступан свим младима без дискриминације, чиме се омогућују једнаке могућности дечацима и девојчицама, уз уважавање посебних потреба сваког старосног узраста. Улога физичких активности у образовању деце, стицању моторичких способности, стицању друштвених способности и очувању здравља је изузетно битна. При том, добробит детета, без обзира на узраст, увек мора бити најважнији циљ. Практично организовање спортских активности је општеприхваћено као сврсисходно за децу и омладину и има позитиван утицај на њихов физички, ментални, психолошки и друштвени развој. Генерално, спорт се сматра нарочито погодном активношћу за физичку и менталну добробит деце и суштински је битан за превенцију здравствених проблема. За свестрани развој детета од кључног значаја је одговарајуће физичко образовање у школи и бављење ваннаставним спортским активностима у школским спортским секцијама и школским спортским друштвима. Сви млади треба да добију адекватно физичко образовање и стекну основне спортске вештине у оквиру редовног наставног програма или у оквиру ваннаставних активности, чиме се омогућава свакодневно бављење спортом. Школе треба да учине младима привлачним да своје слободно време проведу на отвореном простору играјући различите игре, као и да одговоре на прихватљиве нове трендове у спорту. Квалитет физичког образовања и спортске обуке треба да буде обезбеђен и унапређен кроз квалификоване наставнике физичког образовања, уз одговарајуће мере за надзор квалитета. Школе би требало да све младе, а посебно оне у завршним разредима упознају са локалним спортским клубовима и објектима и да остваре сарадњу са локалним спортским клубовима. Млади треба да знају које могућности имају у локалу, како могу да наставе да се баве спортом након завршетка школе, те да буду свесни које то активности највише воле и које их највише стимулишу. Све школе треба да имају неопходну и одговарајућу опрему и објекте за бављење младих физичким активностима и спортом" (Стратегија развоја спорта у Републиии Србији за период 2014-2018, 2014, стр. 16).

Поменимо и предлог актуелног министра просвете, науке и технолошког развоја Младена Шарчевића према коме ће се од наредне школске године (2017/18) ученици виших разреда основних школа свакодневно бавити спортским активностима уместо трећег часа физичког 
васпитања, односно изабраног спорта. Наиме, према овом новом предлогу, уместо трећег часа физичког васпитања, ученици ће имати спортске активности три пута недељно од по пола сата:

\begin{abstract}
„У сарадњи са Друштвом педагога физичке културе разрадићемо целу идеју, а очекујемо и предлоге школа. Ми ћемо школама понудити неколико модела, али ће оне имати слободу да саме осмисле како ће то спровести у пракси. Ако буде новца покушаћемо већ од наредне школске године да вратимо целодневне спортске дане и да другачије планирамо школски календар. Бројни спортски савези су исказали жељу да се укључе и помогну, па ће Министарство просвете сарађивати са Министарствима здравља и омладине и спорта,
\end{abstract}

Осим препознавања значаја школског спорта, физичког васпитања и физичке активности уопште за физичку и менталну добробит, те за превенцију здравствених проблема, с обзиром на чињеницу да је физичка неактивност први од фактора који негативно утиче на здравље сваког појединца, школски спорт и физичко васпитање још увек нису препознати као могуће превентивне мере против насиља ученика у стратешким документима које смо до сада помињали. Слично, у актуелном предлогу увођења спортских активности као врсте школског спорта од школске 2017/18. године није размотрена могућа улога школског спорта као превентивне мере против насиља ученика.

Сматрамо да школски спорт и физичко васпитање јесу значајни фактори који, поред наведене улоге у превенцији здравствених проблема, могу бити и један облик мере превенције насиља међу ученицима, али и облик мере превенције насиља на спортским манифестацијама. Наиме, сматрамо да би разматрању овог питања требало приступити из перспективе целокупног унапређивања спортске културе од најранијег узраста ученика.

Спортску културу можемо дефинисати као складиште информација и нагомиланог знања, начина мишљења, осећања, веровања и делања везаних за спорт и различите облике спортског понашања, а широка област различитих облика сукоба и насиља у спорту јесте неизоставна тема у разматрању спортске културе. Један од значајнијих сегмената спортске културе јесте етика спорта, која будућим и садашњим спортистима даје оријентире за ваљано спортско понашање које претпоставља бројне етичке принципе као што су: уважавање и поштовање противника, фер-плеј (fair-play), принцип љубави према спорту, принцип „важно је учествовати” насупрот принципу „победе по сваку цену”, принцип некоришћења допинг средстава, принцип стриктне одговорно-

\footnotetext{
${ }^{5}$ Видети: http://www.detinjarije.com/umesto-treceg-casa-fizickog-vaspitanja-osnovci-cese-u-skoli-baviti-sportom-svakog-dana/, приступ 25. 10. 2016. у 00.06.
} 
сти спортисте према коме је спортиста увек одговоран за оно што доспе у његов/њен организам, борба против расизма у спорту итд. Отуда, према ауторима (Раденовић \& Савовић, 2015), етика спорта изучава и понашање на спортским догађајима, начин навијаштва, као и испољавање хулиганизма и вандализма на спортским приредбама, делање организованих навијачких група итд.

Поменути етички принципи који чине окосницу етике спорта, као што су уважавање и поштовање противника и фер-плеј, могу бити транспоновани на сложену област бројних друштвених интеракција у свакодневном животу људи, те свакако и на поље друштвених интеракција међу ученицима различитог узраста. У оквиру наставе физичког васпитања, то јест у оквиру школског спорта, осим учења бројних игара и спортова, као и унапређивања властите физичке културе и превенције здравствених проблема, неизоставна је област вредности, норми, правила, тачније, поменутих етичких принципа који прате сваки спорт, игру или вештину, а која може бити значајна мера превенције насиља између ученика. Принцип уважавања и поштовања противника, као и фер-плеј, јесу основни принципи који се могу транспоновати на поље бројних интеракција у свакодневном животу свих људи, а нарочито деце, тачније ученика, који би од најранијег узраста требало да буду упознати са поменутим принципима који могу бити један вид превенције насиља међу ученицима.

Ако је могуће саставити и специфичне програме превенције насиља на спортским догађајима са којима се упознају будући наставници физичког васпитања, као и будући тренери у оквиру свог образовања и усавршавања, сматрамо да је могуће сличне програме користити као превенцију насиља међу ученицима у школама. Програми би обухватали теоријски и практични део. Теоријски део био би састављен не само од релевантних теоријских разматрања у вези са могућим објашњењима појаве насиља како на спортским догађајима тако и уопште, у свакодневном животу, па и у школама већ и од сазнања о значају спортске културе за појединца и за друштво, те о значају етике спорта за појединца и за друштвену заједницу. Практични део програма био би састављен од бројних стварних и хипотетичких примера различитих облика конфликата, сукоба и насиља у спорту и шире, међу ученицима и примера ненасилног решавања конфликата. Сматрамо да цео приступ израде оваквих програма претпоставља један мултидисциплинаран тим састављен од педагога, психолога и социолога, али и професионалаца из области физичке културе (наставници физичког васпитања, тренери, судије). Програме би спроводили наставници физичког васпитања и тренери у оквиру наставе физичког васпитања и у оквиру школског спорта заједно са ученицима, наставницима школе и родитељима ученика (Раденовић et al., 2015).

Због све већег испољавања насиља не само на спортским манифестацијама, како смо помињали, већ уопште, у целом друштву, те због 
присуства тренда „нормализације насиља”, у свим сегментима друштва, предложен програм школског спорта и наставе физичког васпитања био би не само облик превенције насиља међу ученицима већ један од начина унапређења целокупне спортске културе и физичке културе у најширем смислу. Најзад, подсетимо на чињеницу из историје физичке културе и олимпизма која указује на значај и узвишеност спортских манифестација: током трајања Олимпијских игара, антички грчки полиси прекидали су веома честе ратове и непријатељства (,олимпијско примирје") баш због значаја и узвишености спортског надметања.

\section{ЗАКљУЧАК}

Према резултатима истраживања, непромењен степен насиља међу ученицима у Републици Србији у школама може се тумачити не само све присутнијим процесом нормализације насиља у целом друштву већ и недовољним ангажовањем школа у примени стратешких докумената као што су Посебан протокол за заштиту деце и ученика од насиља, злостављања и занемариваға у образовно-васпитним установама из 2007. године и Правилник о протоколу поступања у установи у одговору на насиье, злостављағе и занемаривање из 2010. године. У оквиру ових стратешких докумената не предлаже се могућност, нити се разматра значај школског спорта у превенцији насиља ученика. Слично, ни Стратегија развоја спорта у Републичи Србији за период 20142018. године не препознаје значај школског спорта у превенцији вршњачког насиља. Можда је непрепознавање школског спорта као могуће мере превенције насиља у школама међу ученицима још један од фактора који су утицали на непромењен степен насиља међу ученицима у школама. Зато сматрамо да би убудуће требало размотрити могућност стварања програма који би кроз систем школског спорта, те наставе физичког васпитања у школама били још једна мера превенције насиља међу ученицима у школама. У том смислу, улога и значај школског спорта обухватали би поред унапређења здравствене културе ученика, тачније, превенције здравствених проблема, превенцију различитих облика насиља између ученика у школама, те унапређење и развој спортске културе и физичке културе уопште. Непромењен степен насиља међу ученицима у Републици Србији у школама одсликава снажну тенденцију нормализације насиља у друштву, па се може претпоставити да ће се таква тенденција наставити. Како досадашње мере превенције нису дале очекиване резултате у смањењу степена насиља међу ученицима у школама у Србији, може се претпоставити да увођење школског спорта и могућност његове улоге у превенцији насиља може бити посве ново и ефективно решење уз, свакако, велико ангажовање наставника физичког васпитања и неопходну подршку припадајуће друштвене заједнице. 


\section{ЛИТЕРАТУРА}

Антонић, J. (2015). Превениија насиља у сnорту [Prevention of Violence in Sport], (завршни рад). Retrieved from http://www.vbs.rs/scripts/cobiss?command $=$ SEARCH\&base $=$ colib\&select $=(\mathrm{si}=70214) \&$ lani $=$ SC .

Бабовић, М. (2015). Теоријски и истраживачки приступи у проучавању структурног, културног и директног насиља [Theoretical and Research Approaches in the Study of Structural, Cultural and Direct Violence]. Социологија, 57(2), 331-352. doi:10.2298/SOC1502331B.

Bašelj, A. (2015). Športna diplomacija [Sports Diplomacy], (мастер рад). Retrieved from http://dk.fdv.uni-lj.si/diplomska_dela_.

Бењак, Т., Штефанчић, В., Иванић, М. \& Драушник, Ж. (2016). Праћење насиља над особама с инвалидитетом темељем података Хрватског регистра о особама с инвалидитетом [Monitoring of Violence against Persons with Disabilities Based on the Data of the Croatian Register of Persons with Disabilities]. Хрватски часопис за јавно здравство, 12(45), 16-18.

Вејновић, Д. \& Павловић, Г. (2012). Насилно понашање навијачких група на спортским приредбама - утакмицама у Републици Српској и Босни и Херцеговини [Violent Behaviour of Supporters Groups at Sporting Events - the Matches in the Republic of Srpska and Bosnia and Herzegovina]. У: Симовић, С. (Прир.), Антрополошки аспекти спорта, физичког васпитања и рекреације: зборник радова III међународног научног скупа „Антрополошки аспекти спорта, физичког васпитања и рекреације”, (161-172). Бања Лука: Факултет физичког васпитања и спорта. doi:10.5550/SP.3.2011.19.

Ђорђевић, И. (2016). О фудбалу, антропологији и транзицији. Наративи о насиљу и безбедности у савременој Србији [Of Football, Anthropology and Transition. Narratives about Violence and Safety in Contemporary Serbia]. Етноантрополошки проблеми [Issues in Ethnology and Anthropology], 7(2), 431-447.

Ђорђевић, И. (2015). Антрополог међу навијачима [Anthropologist among Sports Fans]. Београд: Библиотека XX век.

Заштитник грађана. Заштита деие од насиља у школама. Извештај заштитника грађана и панела младих саветника [Protecting Children from Violence in Schools. The Report of the Ombudsman and the Panel of Youth Advisers]. (2011).

Јовановић, М. Д. (2013). Аксиолошки аспекти неетичког понашања спортиста и навијача [Axiological Aspects of Unethical Behavior of Athletes and Sports Fans]. Менаимент у сnорту [Menagement in Sports], 4(1), 25-34.

Коковић, Д. (2010). Друштво, насиље и сnорm [Society, Violence, Sport]. Нови Сад: Mediterran Publishing.

Коковић, Д. (1990). Доба насиља и сnорm [The Era of Violence and Sport]. Нови Сад: Sports' World.

Оташевић, Б. \& Секереш, В. (2015). Предиктори навијачког идентитета: демографски показатељи, димензије ревидираног Grayovog модела и когниције о насиљу [Predictors of Sports Fan Identification: Demograpfics, Revised Reinforcement Sensitivity Theory Dimensions and Violent Cognitions]. Примењена психологија [Applied Psychology], 8(4), 453-469. doi: 10.19090.

Посебни протокол за заштиту деце и ученика од насиља, злостављања и занемаривања у образовно-васпитним установама [Special Protocol for the Protection of Children and Students from Violence, Abuse and Neglect in Educational Institutions]. Министарство просвете Р. Србије, 2007. 
Правилник о протоколу поступања у установи у одговору на насиље, злостављање и занемаривање [Rulebook on the Protocol for Treatment in the Institution in Response to Violence, Abuse and Neglect]. Службени гласник Р. Србије, бр. 30 (2010).

Раденовић, С. (2014). Спорт и друштво - Социологија са сочиологијом спорта. Социологија сnорта [Sport and Society - Sociology with Sociology of Sport. Sociology of Sport]. Београд: Факултет спорта и физичког васпитања Универзитета у Београду.

Раденовић, С. (2012). Биоетика и насиље [Bioethics and Violence]. Годишъак Катедре за друштвене и хуманистичке знаности у медицини Медичинског факултета Свеучилишта у Ријеци, 3(5), 205-218.

Раденовић С. \& Савовић, Б. (2015). Социолошко-педагошке перспективе превенције насиља на спортским догађајима [Socio-pedagogical Perspectives of Violence Prevention in Sports Events]. У: Зборник радова Друге међународне научне конференције „Менаимент безбедности спортских такмичења Превенција насиьа и недоличног понамаға на спортским догађајима", (106-109). Београд: Факултет за спорт Универзитет „Унион-Никола Тесла”.

Рицијаш, Н., Додиг Хундрић, Д. \& Кранжелић, В. (2015). Спортско клађење и друга ризична понашања хрватских средњошколаца [Sports Betting and other Risk Behaviour among Croatian High-school Students]. Хрватска ревија за рехабилитаиијска истраживања , 51(2), 41-56.

Спасић, Д. (2013). Насиље као предмет изучавања криминолошких наука [Violence as a Case Study of Criminological Science].

Зборник радова [Proceedings], 1, (стр. 218-233). Retrieved from https://zbornici. fkn.unsa.ba/index.php/zbornik/article/download/36/37.

Стратегија развоја спорта у Републици Србији за период 2014-2018, [Sports DevelopmentStrategy in the Republic of Serbia for the period 2014-2018]. Службени гласник Р, Србије, Бр. 1 (2015).

Трипковић, М. (2007). Насиље [Violence]. У: А. Мимица, М. Богдановић (Прир.), Сочиолошки речник [Dictionary of Sociology], (стр. 346-347). Београд: Завод за уџбенике.

Cashmore, E. \& Cleland, J. (2012). Fans, homophobia and masculinities in association football: Evidence of a more inclusive environment. The British Journal of Sociology, 63, 370-387. doi: 10.1111/j.1468-4446.2012.01414.x.

Извори са интернета:

http://www.detinjarije.com/umesto-treceg-casa-fizickog-vaspitanja-osnovci-ce-se-u-skolibaviti-sportom-svakog-dana/. 


\title{
THE ROLE AND IMPORTANCE OF SCHOOL SPORT IN THE PREVENTION OF VIOLENCE
}

\author{
Sandra Radenović, Slađana Mijatović \\ University of Belgrade, Faculty of Physical Education and Sport, Belgrade, Serbia
}

\begin{abstract}
Summary
The presence of violence among students in schools in Serbia is one of the phenomena studied within the field of numerous humanities. It can be argued that there are at least two reasons why the level of violence among students in schools in Serbia is unchanged despite the adoption of strategic documents from 2007. and 2010. on the prevention of violence in schools. One of the reasons is the normalization of violence as a process that characterizes all segments of modern society in Serbia and that promotes violence as an acceptable and desirable form of behavior. It can be argued that the trend of normalization of violence in contemporary Serbia continues to strengthen. Another possible reason may be a lack of recognition of school sport as a measure of prevention of violence among students in schools. Namely, in the strategic document under the title "Strategy for the Development of Sport in the Republic of Serbia from 2014 to 2018." the school sport is recognized solely as a measure of prevention of numerous health problems, and as a key factor in improving the physical and mental well-being of students in primary and secondary schools in Serbia. Hence, we believe that in the future, in addition to the mentioned role of the school sport, we should insist on school sports as a measure of prevention of violence among students. We should consider the possibility of creating a programme through a system of school sports and physical education in schools as another measure of prevention of violence among students in schools in the function of contribution to the improvement of the entire sports culture of our society. Programmes would include theoretical and practical part. The theoretical part would be referred to the complex area of understanding numerous forms of violence, while the practical part of the programme would include real and hypothetical examples of numerous conflicts in the sport and their non-violent solutions in the spirit of "fair play". The programmes would be created by a multidisciplinary team consisting of numerous professionals from the field of sport and physical culture. Exemplary and valid sportsmanship within the school sport which presupposes the application of ethical principles such as the principle of "respect for opponent", and "fair play" can be transposed to the complex field of everyday communication between students and the learning of nonviolent conflict resolution. School sport as a measure of prevention of violence among students assumes significant involvement of physical education teachers and coaches through the implementation of the mentioned programmes within the physical education classes and school sport.
\end{abstract}

